\title{
Accumulation efficiency of sunflower for lead and cadmium along with sustainable crop productivity under soil stress
}

\author{
Vinothkumar Vadivel \\ Department of Soil Science and Agricultural Chemistry, Faculty of Agriculture, Annamalai \\ University, Annamalai Nagar-608002, India \\ Senthilvalavan Pitchamuthu* \\ Department of Soil Science and Agricultural Chemistry, Faculty of Agriculture, Annamalai \\ University, Annamalai Nagar-608002, India \\ *Corresponding author. E-mail: senvalavan_m2002@yahoo.co.in
}

\begin{abstract}
By nature coastal saline soils having several constraints in crop production in addition to that of heavy metals contamination deteriorate the soil productivity. To restore these contaminated soils, various remediation techniques in practices must be revamped. The present study was conducted to enhance the accumulation of heavy metals lead and cadmium in sunflower and improve the crop productivity using organic and inorganic soil amendments along with NPK fertilizers in completely randomized design. Soil samples were admitted to estimating soil physico chemical properties and DTPA extractable lead $(\mathrm{Pb})$ and cadmium $(\mathrm{Cd})$ and plant samples analyzed for DTPA extractable $\mathrm{Pb}$ and $\mathrm{Cd}$ concentrations under ICP-OES. The physico-chemical properties and DTPA extractable $\mathrm{Pb}$ and $\mathrm{Cd}$ concentrations were significantly influenced by amendments. Sunflower exhibited significant differences concerning accumulation of $\mathrm{Pb}$ and $\mathrm{Cd}$ against amendments tested along with higher biomass production. Higher shoot and root concentration of $\mathrm{Pb}$ $\left(0.72,0.81\right.$ and $\left.0.94,0.97 \mathrm{mg} \mathrm{kg}^{-1}\right)$ and $\mathrm{Cd}\left(1.78,2.32\right.$ and $\left.0.35,0.32 \mathrm{mg} \mathrm{kg}^{-1}\right)$ were recorded in the treatment RDF + EDTA, which was followed by RDF + Potassium humate and RDF + Zeolite application at 45 DAS and at harvest. Remediation efficiency of sunflower increased by application of RDF + EDTA through enhanced solubility of $\mathrm{Pb}$ and $\mathrm{Cd}$ in soil and thus increased $\mathrm{Pb}$ and $\mathrm{Cd}$ accumulation in root and shoot of sunflower. Whereas, the application of RDF+ FYM or press mud reduced the bioavailability of $\mathrm{Pb}$ and $\mathrm{Cd}$ in soil and thus restricted the accumulation of $\mathrm{Pb}$ and $\mathrm{Cd}$ by sunflower. Further, application of NPK fertilizers maintained the availability of nutrients and enhanced the yield of sunflower. The application of EDTA along with NPK fertilizer enhanced the bioaccumulation of lead and cadmium by sunflower without yield loss. Since, there is a possibility to cause leaching of HMs to ground water by EDTA. Hence, RDF plus Potassium humate or Zeolite can be recommended for lead and cadmium removal by sunflower in coastal saline soils with no loss in crop productivity.
\end{abstract}

Keywords: Cadmium, EDTA, Lead, Potassium humate, Remediation efficiency, Sunflower, Zeolite

\section{INTRODUCTION}

Polluting soil and water by toxic heavy metals (HMs) have become a serious environmental hitch leading to a reduction in plant growth and development; and risk to human health via the food chain Rizwan et al.,2016b; Shaheen and Rinklebe,2015). Excessive heavy metal concentration in plants affect their physiochemical routine and cause oxidative stress in plants via the production of reactive oxygen species (ROS) (Jabeen et al.,2016). Phyto-management with other technologies (phytoremediation, phytomining and biofortification) for mitigating any environmental risk associated with contaminated soils is a cost-effective way (Robinson et al.,2009). The

\section{Article Info}

https://doi.org/

10.31018/jans.v11i3.2134

Received: June 25, 2019

Revised: July 23, 2019

Accepted: August 25, 2019

\section{How to Cite}

Vinothkumar. V and Senthilvalavan. P. (2019) Accumulation efficiency of sunflower for lead and cadmium along with sustainable crop productivity under soil stress. Journal of Applied and Natural Science, 11(3): 636- 644 https://doi.org/10.31018/ jans.v11i3.2134 
tial for plant growth (Pendias and Pendias,2010). The main source of $\mathrm{Cd}$ contamination are industries using cadmium and the other sources are mining, ore dressing and smelting of cadmium sulphide ore etc. Excessive build up of $\mathrm{Pb}$ in soil, water and air is likely due to mining, smelting, manure, sewage sludge and vehicle exhausts. During the past decades, the annual widespread release of heavy metals reached $22,000 \mathrm{t}$ for $\mathrm{Cd}$ and 7, 38,000 t for $\mathrm{Pb}$ (Alloway, 1995; Singh and Tiwari,2003). Solubility of heavy metals in soil depends on various biogeochemical properties and in turn affects the bioavailability of toxic heavy metals. Apart from solubility of heavy metals, plants should have apt mechanism of taking up the HMs from rhizospheric to phyllospheric part by producing more plant biomass under stress. To modify or influence the soil and plant continuum, amendments may require to supply along with macro nutrient fertilizers are must for normal growth and development. Soil application of organic (FYM, press mud), inorganic amendments (Lime, gypsum, humate compounds, zeolite) and chelates like EDTA, AB-EDTA are common in the HMs solubilization or im(mobilization) in soil solution. All these amendments have nature of influencing different soil physico-chemical and biological properties according to their characteristic features.

Sunflower (Helianthus annuus L.) is a proven plant species for bioaccumulation and phytoremediation of HMs (Cornu et al., 2016; Niu et al.,2007). Roots are the main pathway through which HMs gain access to apical parts, the uptake varies with soil properties, plant cultivars and concentration in soil solution (Kolbas et al., 2014; Chaves et al.,2011). Translocation factor is the ratio of the metal concentration in the shoots to that in the roots, which indicates the phytoextraction potential (Adesodun et al., 2010). Various studies have been conducted in phytoextraction of heavy metals using sunflower with less or no details about the soil physical properties especially soil texture and its relations to HMs bioavailability and crop productivity in coastal saline soils. Keeping this in view, this study was taken up to estimate the accumulation efficiency of sunflower for lead and cadmium along with sustainable crop productivity under stress soil habitat using soil amendments and nutrient supplements.

\section{MATERIALS AND METHODS}

Experimental site and soil: The pot culture experiment was carried out to evaluate the effect of molecular fertilizers (NPK) combined with soil amendments (organic and inorganic) on soil physico-chemical properties, DTPA extractable heavy metals $(\mathrm{Pb}$ and $\mathrm{Cd})$ and phytoaccumulation efficiency of heavy metals $\mathrm{Pb}$ and $\mathrm{Cd}$ using sunflower as a test crop in sandy clay loam soil at pot culture yard in the Department of Soil Science and Agricultural Chemistry, Faculty of Agriculture, Annamalai University, Annamalainagar during July October, 2017. Contaminated soil containing 9.60 $\mathrm{mg} \mathrm{kg}^{-1}$ and $76.10 \mathrm{mg} \mathrm{kg}^{-1}$ of total cadmium and lead concentration and DTPA extractable concentration of cadmium was $0.75 \mathrm{mg} \mathrm{kg}^{-1}$ and the lead was $1.56 \mathrm{mg} \mathrm{kg}^{-1}$, respectively. The experimental soil was sandy clay loam in nature with the $\mathrm{pH}$, EC, CEC and organic carbon status of $7.81,0.72$ $\mathrm{d} \mathrm{Sm}^{-1}, 13.52 \mathrm{c} \mathrm{mol}\left(\mathrm{P}^{+}\right) \mathrm{kg}^{-1}$ and $0.41 \mathrm{~g} \mathrm{~kg}^{-1}$, respectively. The available NPK status of soil was low, medium and low (178.2 kg ha $\mathrm{kg}^{-1}, 11.3 \mathrm{~kg} \mathrm{ha}^{-1}$ and $146.8 \mathrm{~kg} \mathrm{ha}^{-1}$, respectively). The experiment was laid out in completely randomized block design, which comprised of eight soil amendments as treatments with recommended dose of molecular fertilizers [NPK @ 60: 90: $60 \mathrm{~kg} \mathrm{ha}^{-1}$ ) with three replications. The experimental soil was filled in cement pot of $30 \mathrm{~cm}$ height according to the experimental design.

Experimental pot preparation, application of amendments and rising of plants: The contaminated soil was amended with recommended dose of fertilizers (RDF) $\left[T_{2}-R D F+\right.$ Farm yard manure, $\mathrm{T}_{3}-\mathrm{RDF}+$ Pressmud, $\mathrm{T}_{4}-\mathrm{RDF}+\mathrm{EDTA}, \mathrm{T}_{5}-\mathrm{RDF}$ + Lime, $\mathrm{T}_{6}-\mathrm{RDF}+$ gypsum, $\mathrm{T}_{7}-\mathrm{RDF}+$ Potassium Humate, $T_{8}-$ RDF + Zeolite, $T_{1}-$ Control $(100 \%$ RDF)] different amendments (organic and inorganic) selected for the study were applied as per the treatment schedule. Sunflower seeds (Sunbred hybrid) were sown and two healthy seedlings were maintained up to 95 days. Pots were filled with $24 \mathrm{~kg}$ of contaminated soil(no heavy metals were spiked artificially). Experimental pots were maintaining at $50-60 \%$ of water holding capacity of the soil. The soil and plant samples at $45^{\text {th }}$ day and harvest were taken and processed for analysis. Molecular fertilizers (NPK) applied as urea,single super phosphate (SSP), muriate of potash (MoP) @ 60:90:60 $\mathrm{kg} \mathrm{ha}^{-1}$ and the viz., farm yard manure (FYM) 6.5, press mud (PM) 2.5, disodium salt of ethylene diamine tetra acetic acid (EDTA) - 0.5, Lime -1.25, Gypsum - 1.25, Potassium Humate (KH) -0.005 , Natural Zeolite (NZ) - $10 \mathrm{~g} \mathrm{~kg}^{-1}$ of soil, respectively.

Yield and yield parameters: The diameter of the head/capitulum of tagged plants were measured at harvest and expressed in $\mathrm{cm}$. The number of filled seeds capitulum ${ }^{-1}$ was counted separately for the tagged plants by gently pressing the seeds in between the thumb and fore finger. Mean of the plants was taken as number of filled seeds per capitulum. Hundred filled seeds were counted randomly from each replication and were weighed. The mean weight was calculated and expressed in grams. The capitulum harvested from each pot were threshed, cleaned and dried to about 10-12 per cent moisture and yield per plant was record- 
ed and expressed as grams plant ${ }^{-1}$. The stovers (after removing the head) from each pot were dried completely in the sun for a week, weighed and expressed in grams plant ${ }^{-1}$.

Soil analysis: Soil $\mathrm{pH}$ was measured in suspension of (1:2.5 soil: water) using a glass electrode standardized with $\mathrm{pH} \mathrm{4,7}$ and 9.2 buffer tablets attached to an Ion analyzer, conductivity was measured in the same suspension using a conductivity meter and cation exchange capacity was determined by neutral normal ammonium acetate method (Jackson,1973). Organic carbon content was determined by modified Chromic acid wet digestion titration method (Walkley and Black,1934). The available nitrogen was determined by alkaline permanganate method (Subbiah and Asija,1956), available phosphorus (using $0.5 \mathrm{M} \mathrm{NaHCO}_{3}$ of $\mathrm{pH} 8.5$ ) was quantified by the spectrophotometer method (Olsen et al.,1954) and available potassium (using neutral normal ammonium acetate extract) was determined by Flame photometric method (Standford and English,1949).

Analysis of heavy metals in soil and plant: Soil and plant samples $(1 \mathrm{~g})$ were digested after adding tri-acid mixture $\left(\mathrm{HNO}_{3}, \mathrm{H}_{2} \mathrm{SO}_{4}\right.$, and $\mathrm{HClO}_{4}$ in 5:1:1 ratio) at $80^{\circ} \mathrm{C}$ until a transparent solution was obtained (Allen et al.,1986). After cooling, the digested sample was filtered using Whatman no. 42 filter paper and the filtrate was finally maintained to $50 \mathrm{ml}$ with distilled water. Concentrations of heavy metals in the filtrate of digested soil and plant samples were estimated by using Inductively Coupled Plasma optical Emission Spectrometer (Model-ICP-OES-5110, Agilent).

To evaluate the ability of metal phytoextraction / phytoaccumulation by sunflower, the certain parameters were considered i.e. a) plant biomass (dry weight of roots and shoots), b) metal concentration in plant tissues (roots and shoots), c) translocation factors (TFs) calculated as the metal in shoots to the metal in roots ratio suggested by Zhixin et al. (2009) and d) bio-concentration factors (BCFs and ER) of shoots and roots calculated as the ratio between metal concentration in plant tissues (shoots or roots, respectively) and total metal initial soil concentration suggested by Elouear et al.,(2016). Remediation efficiency (ER) was calculated using the amount of heavy metal uptake (Concentration in aerials multiplied with its weight) by plants from the soil (concentration in soil multiplied with soil weight).

Statistical analysis: The data of heavy metal concentrations and soil properties of different amendments were subjected to one way analysis of variance (ANOVA). All the statistical tests were performed using SPSS software. The significant differences between the means were tested against the critical difference at $5 \%$ probability level.

\section{RESULTS}

pH, EC, CEC and SOC: All amendments applied were influenced the $\mathrm{pH}, \mathrm{EC}, \mathrm{CEC}$ and SOC of contaminated soil compared to untreated soil (Table 1). The higher $\mathrm{pH}$ values were observed in $\mathrm{RDF}$ plus lime (8.37 and 8.35) and it was on par with RDF plus zeolite (8.33 and 8.3) amended pots at both stages (45 DAS and harvest). Higher EC values of treated soil were noted in RDF plus lime (0.95 and $0.87 \mathrm{dSm}^{-1}$ ) applied pots at 45 DAS and harvest, respectively. Which was followed by RDF plus zeolite applied pots $\left(0.85\right.$ and $\left.0.8 \mathrm{dSm}^{-1}\right)$ and other treatments followed in the order of $T_{7}, T_{3}, T_{1}$, $T_{6}, T_{2}$ and $T_{4}$ (which recorded the lowest $E C$ of 0.35 and $0.27 \mathrm{dSm}^{-1}$ ), respectively at 45 DAS and harvest stages of crop growth. Regarding cation exchange capacity (CEC) and soil organic carbon (SOC) content of soil at 45 DAS and harvest, the higher values were notified under RDF plus FYM amended pots of 15.53 and $16.13\left[\mathrm{Cmol}\left(\mathrm{p}^{+}\right) \mathrm{Kg}^{-1}\right]$; 0.65 and $0.73 \mathrm{~g} \mathrm{~kg}^{-1}$, respectively and it was on par with RDF plus press mud amended pots. Whereas all other soil amendments following in the order of $T_{1}, T_{4}, T_{6}, T_{7}, T_{8}$ and $T_{5}$ (which recorded the lowest CEC of 8.24 and $7.75\left[\mathrm{Cmol}\left(\mathrm{p}^{+}\right) \mathrm{Kg}^{-1}\right)$; 0.08 and $0.08 \mathrm{~g} \mathrm{~kg}^{-1}$ ] respectively.

Heavy metals ( $\mathrm{Pb}$ and $\mathrm{Cd}$ ) concentration in soil: Significantly higher values of DTPA extractable $\mathrm{Pb}$ and $\mathrm{Cd}$ (3.98 and 1.19; 3.85 and $1.31 \mathrm{mg}$ $\mathrm{kg}^{-1}$, respectively) were observed in RDF plus EDTA $\left(T_{4}\right)$ amended pots, respectively and this was followed by potassium humate, zeolite and lime applied pots. But the lower elemental concentration of DTPA extractable $\mathrm{Pb}$ and $\mathrm{Cd}(0.75$ and $0.57 ; 0.62$ and $0.51 \mathrm{mg} \mathrm{kg}^{-1}$, respectively) were observed in the treatment amended with RDF plus FYM $\left(T_{2}\right)$ both at 45 DAS and at harvest (Table 2). Heavy metals $(\mathrm{Pb}$ and $\mathrm{Cd}$ ) concentrations in plant: Maximum lead $(\mathrm{Pb})$ and cadmium $(\mathrm{Cd})$ concentration in shoot and root at 45 DAS and at harvest were recorded in RDF plus EDTA $\left(\mathrm{T}_{4}\right)$ amended pots of $0.72,1.78 ; 0.81,2.32 \mathrm{mg} \mathrm{kg}^{-1}$ and 0.94 , $0.35 ; 0.97,0.32 \mathrm{mg} \mathrm{kg}^{-1}$, respectively. This was followed by other amendments in the order of potassium humate, zeolite, lime, gypsum, 100 per cent RDF alone (control), press mud and FYM. However, Press mud and FYM amended pots on par with each other at both stages (Table 3). Whereas, the lower concentration of $\mathrm{Pb}$ and $\mathrm{Cd}$ in shoot and root $\left(0.09,0.11 ; 0.03,0.6 \mathrm{mg} \mathrm{kg}^{-1}\right.$ and $0.19,0.08 ; 0.15,0.05 \mathrm{mg} \mathrm{kg}^{-1}$, respectively) were observed in the treatment received RDF + FYM $\left(\mathrm{T}_{4}\right)$.

Bio-concentration factor (BCF): values with respect to $\mathrm{Pb}$ and $\mathrm{Cd}$ are $<1$ indicating that the concentration of the elements does not exceed its content in the soil and BCF values of $\mathrm{Cd}$ were higher than that of $\mathrm{Pb}$ in the trial at both stages of crop. According to the BCF values obtained for $\mathrm{Pb}$ and $\mathrm{Cd}$ accumulated by sunflower were higher 
Vinothkumar. V and Senthilvalavan. P. / J. Appl. \& Nat. Sci. 11(3): 636- 644 (2019)

Table 1. Effect of soil amendments on $\mathrm{pH}, \mathrm{EC}\left(\mathrm{dS} \mathrm{m} \mathrm{m}^{-1}\right), \mathrm{CEC}\left(\mathrm{cmol}\left(\mathrm{p}^{+}\right) \mathrm{Kg}^{-1}\right)$ and $\operatorname{SOC}\left(\mathrm{g} \mathrm{kg}^{-1}\right)$.

\begin{tabular}{lcccccccc}
\hline Crop growth stages & \multicolumn{4}{c}{ 45 DAS } & \multicolumn{4}{c}{ Harvest } \\
\hline Treatments /Parameters & pH & EC & CEC & SOC & pH & EC & CEC & SOC \\
\hline T $_{1}$ - Control (100\% RDF) & 7.79 & 0.64 & 13.93 & 0.48 & 7.70 & 0.60 & 14.46 & 0.57 \\
T $_{2}$ - RDF + Farm yard manure & 7.60 & 0.58 & 15.53 & 0.65 & 7.53 & 0.51 & 16.13 & 0.73 \\
$\mathrm{~T}_{3}$ - RDF + Pressmud & 7.80 & 0.72 & 15.15 & 0.57 & 7.78 & 0.65 & 15.78 & 0.68 \\
$\mathrm{~T}_{4}$ - RDF + EDTA & 7.25 & 0.35 & 13.37 & 0.40 & 7.13 & 0.27 & 14.02 & 0.49 \\
$\mathrm{~T}_{5}$ - RDF + Lime & 8.37 & 0.95 & 8.24 & 0.08 & 8.35 & 0.87 & 7.75 & 0.08 \\
$\mathrm{~T}_{6}$ - RDF + Gypsum & 7.61 & 0.50 & 12.66 & 0.24 & 7.51 & 0.41 & 13.32 & 0.37 \\
$\mathrm{~T}_{7}$ - RDF + Potassium humate & 7.75 & 0.80 & 11.41 & 0.29 & 7.71 & 0.76 & 11.98 & 0.29 \\
$\mathrm{~T}_{8}$ - RDF + Zeolite & 8.33 & 0.85 & 9.40 & 0.10 & 8.30 & 0.80 & 8.25 & 0.10 \\
SEd & 0.29 & 0.02 & 0.38 & 0.01 & 0.32 & 0.03 & 0.38 & 0.01 \\
CD (P=0.05) & 0.62 & 0.06 & 0.80 & 0.03 & 0.68 & 0.05 & 0.81 & 0.03 \\
\hline
\end{tabular}

EC-Electrical conductivity, CEC- Cation exchange capacity, SOC-Soil organic carbon

Table 2. Element concentrations of $\mathrm{Pb}$ and $\mathrm{Cd}\left(\mathrm{mg} \mathrm{kg}^{-1}\right)$ in sunflower.

\begin{tabular}{lcccc}
\hline Crop growth stages & \multicolumn{2}{c}{ 45 DAS } & \multicolumn{2}{c}{ Harvest } \\
\hline \multirow{2}{*}{ Treatments /Parameters } & \multicolumn{2}{c}{ DTPA } & DTPA \\
\cline { 2 - 5 } & $\mathbf{P b}$ & $\mathbf{C d}$ & $\mathbf{P b}$ & $\mathbf{C d}$ \\
\hline $\mathrm{T}_{1}$-Control (100\% RDF) & 1.47 & 0.80 & 1.35 & 0.77 \\
$\mathrm{~T}_{2}$-RDF + Farm yard manure & 0.75 & 0.57 & 0.74 & 0.57 \\
$\mathrm{~T}_{3}$ - RDF + Pressmud & 0.87 & 0.61 & 0.62 & 0.51 \\
$\mathrm{~T}_{4}$ - RDF +EDTA & 3.98 & 1.19 & 3.85 & 1.31 \\
$\mathrm{~T}_{5}$-RDF + Lime & 2.97 & 0.97 & 2.86 & 1.05 \\
$\mathrm{~T}_{6}$-RDF + Gypsum & 2.29 & 0.91 & 2.14 & 0.99 \\
$\mathrm{~T}_{7}$-RDF + Potassium humate & 3.57 & 1.12 & 3.45 & 1.23 \\
$\mathrm{~T}_{8}-\mathrm{RDF}+$ Zeolite & 3.12 & 1.04 & 3.01 & 1.15 \\
SEd & 0.08 & 0.02 & 0.07 & 0.03 \\
CD (P=0.05) & 0.17 & 0.06 & 0.16 & 0.06 \\
\hline
\end{tabular}

Table 3. Influence of soil amendments on accumulation of $\mathrm{Pb}$ and $\mathrm{Cd}\left(\mathrm{mg} \mathrm{kg}^{-1}\right)$ in sunflower.

\begin{tabular}{lcccccccc}
\hline Crop growth stages & \multicolumn{4}{c}{ 45 DAS } & \multicolumn{3}{c}{ Harvest } \\
\hline \multirow{2}{*}{ Treatments /Parameters } & \multicolumn{2}{c}{ Shoot } & \multicolumn{2}{c}{ Root } & \multicolumn{2}{c}{ Shoot } & Root \\
\cline { 2 - 9 } & Pb & Cd & Pb & Cd & Pb & Cd & Pb & Cd \\
\hline T1-Control (100\% RDF) & 0.25 & 0.39 & 0.73 & 0.13 & 0.27 & 0.42 & 0.76 & 0.10 \\
T2-RDF + Farm yard manure & 0.09 & 0.19 & 0.11 & 0.08 & 0.03 & 0.15 & 0.06 & 0.05 \\
T3- RDF + Pressmud & 0.13 & 0.25 & 0.25 & 0.09 & 0.07 & 0.21 & 0.10 & 0.06 \\
T4- RDF +EDTA & 0.72 & 0.94 & 1.78 & 0.35 & 0.81 & 0.97 & 2.32 & 0.32 \\
T5-RDF + Lime & 0.51 & 0.65 & 1.21 & 0.21 & 0.57 & 0.69 & 1.63 & 0.19 \\
T6-RDF + Gypsum & 0.37 & 0.52 & 1.01 & 0.17 & 0.48 & 0.56 & 1.28 & 0.14 \\
T7-RDF + Potassium humate & 0.63 & 0.80 & 1.52 & 0.31 & 0.70 & 0.84 & 2.01 & 0.27 \\
T8-RDF + Zeolite & 0.55 & 0.67 & 1.32 & 0.27 & 0.61 & 0.71 & 1.72 & 0.23 \\
SEd & 0.03 & 0.05 & 0.09 & 0.01 & 0.04 & 0.04 & 0.11 & 0.01 \\
CD (P=0.05) & 0.07 & 0.10 & 0.19 & 0.04 & 0.09 & 0.10 & 0.24 & 0.03 \\
\hline
\end{tabular}

(0.036 and $0.97 ; 0.045$ and 0.97 ) with RDF plus EDTA $\left(\mathrm{T}_{4}\right)$ applied plants at 45 DAS and at harvest, respectively and this followed by other treatments in descending order of $\mathrm{T}_{7}, \mathrm{~T} 8, \mathrm{~T}_{5}, \mathrm{~T}_{6}$, $\mathrm{T}_{1}, \mathrm{~T}_{3}$ and $\mathrm{T}_{2}$. RDF plus FYM amended $\left(\mathrm{T}_{2}\right)$ recorded the lowest BCF values of 0.003 and 0.205 ; 0.001 and 0.152 , respectively (Table 5 .

Transfer factor (TF): for lead and cadmium by sunflower was followed a diverse pattern (Table 5. At 45 DAS higher TF value was observed in RDF plus FYM amended plant for $\mathrm{Pb}$ (0.82)and RDF plus lime for $\mathrm{Cd}$ (3.10). At harvest RDF plus press mud recorded the higher TF value for $\mathrm{Pb}(0.70)$ and control treatment $\left(T_{1}\right)$ which registered higher TF of 4.20. Whereas the lower values TF at 45 DAS were recorded by the treatments 100 per cent RDF alone for $\mathrm{Pb}$ (0.34) and RDF plus FYM for $\mathrm{Cd}$ (2.38) and at harvest except press mud, FYM and gypsum all other treatments were registered more or less equal values $(0.35$ to 0.36$)$ for $\mathrm{Pb}$ and RDF plus EDTA recorded lowest TF of 3.03.

Remediation efficiency (ER): There was significantly higher remediation efficiency (ER) of sunflower effected by amendments both at 45 DAS and at harvest (Table 4). RDF plus EDTA were observed highest ER value in amended plants for both $\mathrm{Pb}$ and $\mathrm{Cd}$ (0.68 and 11.06; 2.48 and 34.74) followed by RDF plus zeolite at 45 DAS and potassium humate at harvest. Whereas, the lowest ER values observed in RDF plus FYM amended plants both at 45 DAS and at harvest for both $\mathrm{Pb}$ and $\mathrm{Cd}(0.06$ and $0.66 ; 0.05$ and 1.45 , respectively). 
Vinothkumar. V and Senthilvalavan. P. / J. Appl. \& Nat. Sci. 11(3): 636- 644 (2019)

Table 4. Simple correlation matrix showing relationships between soil available $\mathrm{Pb}$ and $\mathrm{Cd}$ with shoot and root $\mathrm{Pb}$ and $\mathrm{Cd}$ concentration of sunflower.

\begin{tabular}{|c|c|c|c|c|c|c|c|c|c|c|c|c|}
\hline & \multicolumn{6}{|c|}{45 DAS } & \multicolumn{6}{|c|}{ HARVEST } \\
\hline & $\mathbf{P b}$ & Cd & $\mathrm{Pb} \mathrm{S}$ & Cd S & $\mathbf{P b} \mathbf{R}$ & Cd R & $\mathbf{P b}$ & Cd & $\mathrm{Pb} \mathrm{S}$ & $\mathrm{CdS}$ & $\mathbf{P b ~ R}$ & Cd R \\
\hline $\mathbf{P b}$ & 1.000 & & & & & & & & & & & \\
\hline Cd & 0.989 & 1.000 & & & & & & & & & & \\
\hline $\mathrm{Pb} \mathrm{S}$ & 0.996 & 0.986 & 1.000 & & & & & & & & & \\
\hline $\mathrm{Cd} \mathrm{S}$ & 0.990 & 0.983 & 0.996 & 1.000 & & & & & & & & \\
\hline $\mathrm{Pb} \mathbf{R}$ & 0.986 & 0.993 & 0.991 & 0.992 & 1.000 & & & & & & & \\
\hline Cd R & 0.978 & 0.970 & 0.984 & 0.984 & 0.969 & 1.000 & & & & & & \\
\hline $\mathbf{P b}$ & 1.000 & 0.989 & 0.997 & 0.990 & 0.986 & 0.978 & 1.000 & & & & & \\
\hline Cd & 0.991 & 0.997 & 0.985 & 0.978 & 0.988 & 0.964 & 0.991 & 1.000 & & & & \\
\hline $\mathrm{Pb} \mathrm{S}$ & 0.992 & 0.992 & 0.992 & 0.989 & 0.997 & 0.964 & 0.992 & 0.994 & 1.000 & & & \\
\hline $\mathrm{Cd} \mathrm{S}$ & 0.991 & 0.991 & 0.995 & 0.997 & 0.998 & 0.974 & 0.990 & 0.986 & 0.996 & 1.000 & & \\
\hline Pb R & 0.994 & 0.995 & 0.994 & 0.991 & 0.997 & 0.967 & 0.994 & 0.995 & 0.999 & 0.997 & 1.000 & \\
\hline $\mathrm{Cd} \mathrm{R}$ & 0.984 & 0.973 & 0.990 & 0.991 & 0.975 & 0.998 & 0.984 & 0.967 & 0.971 & 0.981 & 0.974 & 1.000 \\
\hline
\end{tabular}

$\mathrm{Pb}$ S: lead concentration in Shoot, Pb R: lead concentration in root, Cd S: Cadmium concentration in Shoot Cd R: Cadmium concentration in root

Table 5. Influence of organic and inorganic amendments on BCF, TF and ER of sunflower.

\begin{tabular}{|c|c|c|c|c|c|c|c|c|c|c|c|c|}
\hline \multirow{3}{*}{$\begin{array}{l}\text { Crop growth stages } \\
\text { Treatments } \\
\text { Parameters }\end{array}$} & \multicolumn{2}{|c|}{45 DAS } & \multicolumn{2}{|c|}{ Harvest } & 45 & AS & \multicolumn{2}{|c|}{ Harvest } & & AS & \multicolumn{2}{|c|}{ Harvest } \\
\hline & \multicolumn{4}{|c|}{$\mathrm{BCF}$} & \multicolumn{4}{|c|}{ TF } & \multicolumn{4}{|c|}{ ER } \\
\hline & $\mathrm{Pb}$ & Cd & $\mathrm{Pb}$ & Cd & $\mathrm{Pb}$ & Cd & $\mathrm{Pb}$ & Cd & $\mathbf{P b}$ & Cd & $\mathrm{Pb}$ & Cd \\
\hline $\begin{array}{ll}T_{1}-\text { Control } & (100 \% \\
\text { RDF }) & \end{array}$ & 0.014 & 0.394 & 0. & 0.394 & 0.34 & 3.00 & 0.36 & 4.20 & 0.11 & 1.62 & 0.39 & 5.67 \\
\hline $\begin{array}{l}\mathrm{T}_{2}-\mathrm{RDF}+\text { Farm yard } \\
\text { manure }\end{array}$ & 0.003 & 0.205 & 0.001 & 0.152 & 0.82 & 2.38 & 0.50 & 3.00 & 0.06 & 0.66 & 0.05 & 1.45 \\
\hline $\mathrm{T}_{3}-\mathrm{RDF}+$ Pressmud & 0.006 & 0.258 & 0.002 & 0.205 & 0.52 & 2.78 & 0.70 & 3.50 & 0.08 & 0.80 & 0.12 & 1.93 \\
\hline $\mathrm{T}_{4}-\mathrm{RDF}+\mathrm{EDTA}$ & 0.036 & 0.977 & 0.045 & 0.977 & 0.40 & 2.69 & 0.35 & 3.03 & 0.68 & 11.06 & 2.48 & 34.74 \\
\hline$T_{5}$-RDF + Lime & 0.025 & 0.652 & 0.032 & 0.667 & 0.42 & 3.10 & 0.35 & 3.63 & 0.11 & 1.41 & 0.67 & 7.80 \\
\hline $\mathrm{T}_{6}-\mathrm{RDF}+$ Gypsum & 0.020 & 0.523 & 0.026 & 0.530 & 0.37 & 3.06 & 0.38 & 4.00 & 0.22 & 3.35 & 0.96 & 11.03 \\
\hline$T_{7}-\mathrm{RDF}+$ Potassium & 0.031 & 0.841 & 0.039 & 0.841 & 0.41 & 2.58 & 0.35 & 3.11 & 0.27 & 3.96 & 1.27 & 16.46 \\
\hline $\mathrm{T}_{8}-\mathrm{RDF}+$ Zeolite & 0.027 & 0.712 & 0.034 & 0.712 & 0.42 & 2.48 & 0.35 & 3.09 & 0.31 & 4.11 & 1.14 & 14.0 \\
\hline
\end{tabular}

BCF-Bio Concentration Factor, TF-Transfer Factor ER- Remediation Efficiency.

Table 6. Influence of soil amendments and NPK fertilizers on crop productivity.

\begin{tabular}{llllll}
\hline Treatments /Parameters & $\begin{array}{l}\text { Head diame- } \\
\text { ter }(\mathbf{c m})\end{array}$ & $\begin{array}{l}\text { No. of seeds } \\
\text { head }^{-1}\end{array}$ & $\begin{array}{l}\mathbf{1 0 0} \\
\text { weight }^{\text {(g) }}\end{array}$ & $\begin{array}{l}\text { Seed yield } \\
\text { g plant }^{-1}\end{array}$ & $\begin{array}{l}\text { Stover } \\
\text { Yield g plant }^{-1}\end{array}$ \\
\hline $\mathrm{T}_{1}$-Control (100\% RDF) & 12.13 & 490.0 & 4.35 & 25.73 & 53.47 \\
$\mathrm{~T}_{2}$-RDF + Farm yard manure & 16.47 & 716.6 & 4.51 & 33.19 & 64.09 \\
$\mathrm{~T}_{3}$ - RDF + Pressmud & 16.01 & 702.3 & 4.43 & 31.73 & 61.77 \\
$\mathrm{~T}_{4}$ - RDF +EDTA & 15.23 & 651.3 & 4.30 & 29.31 & 58.77 \\
$\mathrm{~T}_{5}$-RDF + Lime & 10.43 & 391.2 & 4.32 & 17.64 & 45.56 \\
$\mathrm{~T}_{6}$-RDF + Gypsum & 14.51 & 601.1 & 4.28 & 26.41 & 53.65 \\
$\mathrm{~T}_{7}-\mathrm{RDF}+$ Potassium humate & 13.01 & 544.2 & 4.27 & 21.61 & 50.08 \\
$\mathrm{~T}_{8}$-RDF + Zeolite & 11.18 & 431.0 & 4.19 & 18.93 & 46.71 \\
SEd & 0.96 & 40.28 & 0.29 & 1.66 & 3.49 \\
CD $(\mathrm{p}=0.05)$ & 2.04 & 85.39 & NS & 3.52 & 7.40 \\
\hline
\end{tabular}

Crop productivity: The application of organic and inorganic soil amendments along NPK fertilizers significantly influenced the yield and yield characters of sunflower (head diameter $(\mathrm{cm})$, number of seeds per head, seed yield $\left(\mathrm{g} \mathrm{plant}^{-1}\right)$ and stover yield $\left(\mathrm{g}\right.$ plant ${ }^{-1}$ ) except 100 seed weight $(\mathrm{g})$ of sunflower (Table 6 . Among the treatments, RDF plus FYM $\left(\mathrm{T}_{2}\right)$ recorded significantly maximum head diameter of $16.47 \mathrm{~cm}$ and number seeds head $^{-1}(716.6)$ it was on par with the treatment RDF + pressmud $\left(\mathrm{T}_{3}\right)$ and RDF + EDTA $\left(\mathrm{T}_{4}\right)$.
The minimum head diameter of $11.26 \mathrm{~cm}$ and minimum number seeds head ${ }^{-1}$ of 391.2 were registered by RDF plus lime $\left(T_{5}\right)$ applied plants. Further, application of organic and inorganic soil amendments along with recommended dose of NPK fertilizers did not exert any significant impact on test seed weight of sunflower. Regarding the seed and stover yield, application of RDF plus FYM $\left(\mathrm{T}_{2}\right)$ attained statistical supremacy by recording $33.19 \mathrm{~g} \mathrm{plant}^{-1}$ and $64.09 \mathrm{~g} \mathrm{plant}^{-1}$ of seed and stover yield. However, this treatment was on 
par with treatment RDF + pressmud and RDF plus lime applied plants registered the lowest seed and stover yield of 17.64 and $45.56 \mathrm{~g}$ plant $^{-1}$, respectively.

\section{DISCUSSION}

Possibility of using crops as phytoremediants depends on the accumulation and distribution of metals among their morphological organs. Plants characterized by high biomass production and intensive heavy metals accumulation in shoots and roots can be used as phytoremediants. The availability of heavy metals in the soil depends on chemical speciation of the metal, soil $\mathrm{pH}$ and other soil chemical and physical properties (Smith,2009) and crop productivity depends on the availability of essential nutrient elements.

Physico-chemical properties of the HMs amended soil: Lime amended treatments in heavy metal contaminated soils duly increased soil $\mathrm{pH}$ which depends on $\mathrm{pH}$ of liming material and $\mathrm{C}^{2+}$ concentration in soil solution. Similar records were observed by Rehman et al. (2015b) i.e. addition of lime has positive momentum of increasing soil $\mathrm{pH}$ and $\mathrm{EC}$. Lower values of $\mathrm{pH}$, EC were observed in RDF plus EDTA amended pots $\left(T_{4}\right)$, this might be ascribed due to EDTA's chelating effect (induces variable charge) on growth medium which influences both $\mathrm{pH}$ and $\mathrm{EC}$. There was significant difference in EC, CEC and SOC values among the amendments compared to $\mathrm{pH}$ values. Higher values of CEC and SOC were attributed duly by the addition of farm yard manure (FYM) which increased adsorption sites by increasing negative charges on the soil surface and reducing competing metal cations (Alamgir et al.,2011).

Further, addition of soil organic carbon might be due to accumulation plant residual lignin in FYM directly flows to the structural and metabolic soil carbon pool and increased biologically active soil organic carbon such as microbial biomass carbon and mineralizable carbon While, the lower values of CEC and SOC were recorded by RDF plus lime amended pots. The reduction in CEC and SOC content in lime applied treatments might be caused by lime effect on reducing $\mathrm{pH}$, EC and increasing soluble salts contents. Ever since, both ethylene diamine tetra acetic acid (EDTA) and lime application did not influence this pool. Similar results were reported that manure was the most effective in increasing POM$C$ when compared with urea or without urea or other soil amendments (Mando et al.,2005). i.e. $\mathrm{N}$ supply through organic manures might have stimulated microbial activity and enhances $C$ turnover, which explains the negative values of C stabilization in the fertilizer $\mathrm{N}$ applied plots which was hinder by the RDF plus lime applied treatments.
DTPA extractable heavy metals ( $\mathrm{Pb}$ and $\mathrm{Cd}$ ) concentration in soil: Increased lead and cadmium concentration in soil might be attributed due to enhanced $\mathrm{Pb}$-EDTA and Cd-EDTA complex formation that brought the metals from sorbed sites to the soil solution and increases the bioavailability of $\mathrm{Pb}, \mathrm{Cd}$ and other heavy metals by forming water soluble - chelate complexes and addition of chelating agent and consequent formation of element - chelate complexes prevent precipitation and sorption of the elements in the soil by the amendments applied. Similar reports were given by Freitas and Nascimento (2009) and Suthar et al.,2013. They opined that the formation of metal - chelate complex might be low in energy to bind the metals to become available in soil solution especially organic amendments.In the present study, due to increased sorption sites by FYM through addition of organic carbon, enhancing the CEC and humic substances in the soil by increased the degree of humification. By which HMs may get adsorbed, precipitated or more options of forming complex with $\mathrm{Pb}$ and $\mathrm{Cd}$ in sandy clay loam soil texture having $\mathrm{pH}<8.5$ (even though it registered low $\mathrm{pH}$ values compared to all other treatments except RDF plus EDTA amended one). The low CEC of the soil attests to its low metal immobilization which may result in increased elemental concentration in soil solution in the present study in EDTA and lime amended pots. This conforms with those of Arunakumara et al. (2013) and Lucchini et al. (2014). Higher values of CEC and SOC were observed in FYM amended treatment throughout the crop growth, which results in lower DTPA extractable lead (Pb) and cadmium (Cd) due to immobilization.

Heavy metal concentrations in the plants: Notably higher elemental concentration of $\mathrm{Pb}$ and $\mathrm{Cd}$ in shoot and root of sunflower accumulated by EDTA amended plants. This might be $s$ due to altering soil physico-chemical properties, plants rhizospheric processes, plant variety or cultivar/ hybrid and its uptake mechanisms. Similar reports were given by (Shittu et al.,2015). Further, effects amendments on metal adsorption/desorption, precipitation and or solidification processes might have influenced the mobility of metals. In this study chief mechanism of accumulating $\mathrm{Pb}$ and Cd were identified as chelating effect of EDTA by forming of stable complexes. In addition, increased absorption of $\mathrm{Pb}$ and $\mathrm{Cd}$ from soil into the roots of sunflower and then to shoots attributed by chelating effects of EDTA along with the chelating exudates produced by the sunflower plant roots. Results showed that this treatment had relatively low effect on $\mathrm{Pb}$ concentration in shoot organs of sunflowerand EDTA can solubilise soil $\mathrm{Pb}$ and $\mathrm{Pb}$ EDTA can be easily absorbed by roots of the plant. These results are in line with those of Suthar et al. (2013) who reported that addition of 
chelating agent and the consequent formation of element-chelate complexes prevent precipitation and sorption of the elements in the contaminated calcareous soils of Gujranwala and Pacca. Whereby lower lead and cadmium concentration in sunflower shoot and root were observed in FYM amended plants might be due to increased sorption sites by FYM through addition of organic carbon, enhancing the CEC and humic substances in the soil (Singh and Agarwal,2013) thus HMs may get adsorbed, precipitated or more options of forming complex with $\mathrm{Pb}$ and $\mathrm{Cd}$ which results in higher immobilization of lead and cadmium in soil and lowered the plant uptake. Press mud also show similar trend of activity as FYM in saline sandy clay loam soil. Further, the study results were confirmed by positive correlation with soil available heavy metal concentration after amending the soil with organic and inorganic amendments with shoot and root uptake of lead and cdmium (Table 4) which proved that soil solution availability directly proportional to accumulation of lead and cadmium in root and shoot of sunflower plant.

Remediation efficiency of sunflower: The rate of metal uptake is greatly influenced by plant species, the transfer factor of the metals by each plant species are desirable for classification of the plants phytoaccumulation, phytostabilization and phytoextraction potentials (Chehregani and Malayeri,2007; Ayari et al., 2010). In the present study, remediation efficiency of sunflower was studied by determining bioconcentration factor (BCF) and transfer factor (TF) from the soil and plant elemental concentration of $\mathrm{Pb}$ and $\mathrm{Cd}$ (Table 4). Low BCFs of lead might be due to plants do not take up large quantities of soil lead $(\mathrm{Pb})$ and its low mobility compared to cadmium which is highly mobile in both soil and plant. These results are in line with those of Raymond et al.,2011; Radulescu et al.,2013) in calcareous soils by rapeseed and amaranthus spp. In connection with transfer factor, the results noted that application of RDF plus FYM and or RDF plus press mud led to an increased transfer factor for $\mathrm{Pb}$, however their TF values were less than 1 , which indicates an enhanced ability of plants to accumulate heavy metals in the roots and not to the aerials when compared to other amendments. While, the TF values for $\mathrm{Cd}$ showed a different trend as RDF plus lime, RDF plus gypsum and RDF alone applied treatments showed higher TF values for $\mathrm{Cd}$. TF values of $\mathrm{Cd}$ are three folds of $\mathrm{Pb}$. This might be due to higher mobility of $\mathrm{Cd}$ in plants (roots to shoots) than $\mathrm{Pb}$, which mostly retained in roots itself influenced by these amendments. These results conform with those of Smical et al. (2008) who reported that metals distribution in plant seems to be controlled by some mechanism and this suggests the existence of some boundaries and/ or change in the metal chemical state. Further, the application of RDF plus EDTA $\left(T_{4}\right)$ proved its superiority over other treatments by recording higher remediation efficiency (ER) values of $0.68,2.48$ and $11.06,34.74$ and the lower ER values $(0.06$, 0.05 and $0.66,1.45)$ were observed in RDF plus FYM $\left(\mathrm{T}_{2}\right)$ amended treatments for $\mathrm{Pb}$ and $\mathrm{Cd}$ at 45 DAS and at harvest, respectively. ER values are increases with increase in soil to plant movement of metals which was consistent with the findings of Elouear et al.(2016) in contaminated agricultural soils by alfalfa plants.

Crop productivity: Yield and yield attributes of sunflower [head diameter $(\mathrm{cm})$, number of seeds head $^{-1}$, hundred seed weight $(\mathrm{g})$, seed and stover yield $\left(\mathrm{g} \mathrm{plant}^{-1}\right)$ ] were higher in RDF plus FYM amended pots and it was statistically on par with the application of RDF plus pressmud or EDTA. This might be due to addition of NPK fertilizers along with FYM or press mud resulting in utilization of available resources to a maximum extent with increased nutrient uptake consequently enhanced the various yield attributes which in turn results in higher seed and stover yield of sunflower. Further, improved performance of these treatments is due to continued contribution of soil available nutrients even under stress condition reflected on increased growth and yield attributes. These are in line with those of Sahoo et al. (2009) and (Najundappa et al.,2001). i.e favorable effects of organics on growth and yield attributes also proved by enhanced nutrient uptake, higher photosynthetic assimilates production and effective portioning from source and sink. In addition to that application of FYM might have stimulated the activities of soil MOs that make the plant nutrients readily available to the crops thereby increased photosynthetic rate and hence higher yield (Manjunatha et al.,2009) realized due to increased photosynthetic rates higher root oxidizing activity and nutrient availability (Mishra and Salokhe,2010) leading to better yield. Whereas, the lowest values of yield attributes and seed, stover yields were recorded in plants amended with RDF plus lime might be attributed due reduced availability of macro and micronutrient (Rehman et al.,2015b)thus in reduction plant nutrient uptake resulted reduced yield. Present experimental results are in agreement with those of Ghosh et al.(2010) and Ahmad et al.(2015) they reported in maize plants under nickel and chromium contaminated soils.

\section{Conclusion}

It could be concluded that addition of RDF plus FYM or press mud reduced the bioavailability $\mathrm{Pb}$ and $\mathrm{Cd}$ in soil solution whereas EDTA enhanced the bioavailability and thus induced the accumulation of lead and cadmium in sunflower with sustainable crop productivity. Also, it can be conclud- 
ed that RDF plus potassium humate or Zeolite may be recommended for lead and cadmium removal by sunflower in coastal saline sandy clay loam soils and application of EDTA may also be avoided due to the leaching of its complexes formed due to chelating of HMs that may ultimate lead may lead to ground water contamination. The study results indicated that EDTA along with RDF of NPK molecular fertilizers could be the best amendment for the problem taken but it is discovered that the use of potassium humate or zeolite can beneficial for farmers produce crops in heavy metal contaminated soils especially in coastal areas. This study will help the researchers to uncover the critical areas of remediating heavy metal contaminated soils with different soil textural classes with fluctuating soil salinity that many researchers were not able to explore. Thus it may address a solution to the mass clean-up issues of heavy metal accumulation in different textural soils with salinity problems of the world.

\section{ACKNOWLEDGEMENTS}

The authors acknowledge the Department of Soil Science and Agricultural Chemistry, Faculty of Agriculture, Annamalai University, Annamalai Nagar for providing research facilities cum support and we thank Centre for Advanced Study in Marine Biology, Annamalai University, Annamalai Nagar for analytical works with ICP-OES.

\section{REFERENCES}

1. Adesodun, J.K., M.O. Atayese, T.A. Agbaje, B.A. Osadiaye, O.F. Mafe, and A.A. Soretire. 2010. Phytoremediation potentials of sunflowers (Tithonia diversifolia and Helianthus annuus) for metals in soils contaminated with zinc and lead nitrates. Water. Air. Soil Pollut. 207: 195- 201. doi:10.1007/s 11270-0090128-3.

2. Ahmad, P., M. Sarwat, N.A. Bhat, M.R. Wani, A.G. Kazi and L.P. Tran. 2015. Alleviation of cadmium toxicity in Brassica juncea L. (Czern. \& Coss) by calcium application involves various physiological and biochemical strategies. PLOS ONE., 10(1): 0114571.doi:10.1371/journal.pone.0114571.

3. Alamgir, M., M. G. Kibria and M. Islam. 2011. Effects of farm yard manure on cadmium and lead accumulation in Amaranth (Amaranthus oleracea L.) J. Soil Sci. Environ. Manage., 2(8): 237-240.DOI:10-5897/ JSSEM

4. Allen, S.E., Grimshaw, H.M., Rowland, A.P., 1986. Chemical analysis. In: Moore, P.D., Chapman, S.B. (Eds.), Methods in Plant Ecology. Blackwell Scientific Publication, Oxford, London, pp. 285-344.

5. Alloway, B. J. 1995. The origin of heavy metals in soils. In "Heavy Metals in Soils". (Auoway, BJ., Ed.). Blackie Academic and Professional. London, pp 131152.

6. Arunakumara,. K., B.C. Walpola and M.H. Yoon. 2013. Agricultural methods for toxicity alleviation in metal contaminated soils: a review. Korean J. Soil Sci Fert., 46(2): 73-80.DOI:10.7745/ KJSSF.2013.46.2.073.
7. Ayari, F., H. Hamdi, N. Jedidi, N.Gharbi and R. Kossai. (2010). Heavy metal distribution in soil and plant in municipal solid waste compost amended plots. Int. J. Environ. Sci. Technol., 7(3): 465472.https://doi.org/10.1007/BF03326156.

8. Chang Ed-Haun, Ren-Shih Chungh and Young-How Tsai, 2007. Effect of different application rate of organic fertilizer on soil enzyme activity and microbial population. Soil Science and Plant Nutrition, 53(2): 132140.https://doi.org/10.1111/j.17470765.2007.00122.x.

9. Chaves, L.H.G., M.A. Estrela and R. Sena De Souza. 2011. Effect on plant growth and heavy metal accumulation by sunflower. J. Phytol., 3(12): 4-9. https:// updatepublishing.com/journal/index.php/jp/article/ view/2736

10. Chehregani A., B. Malayeri. 2007. Removal of heavy metals by native accumulators plants. Int. J. Agric. Biol., 9(3): 462-465.

11.Cornu, J.Y., R.Bakoto, O. Bonnard, S. Bussière, C Coriou, C. Sirguey, T. Sterckeman, S.Thunot, M.I. Visse and C. Nguyen. 2016. Cadmium uptake and partitioning during the vegetative growth of sunflower exposed to low $\mathrm{Cd}^{2+}$ concentrations in hydroponics. Plant and Soil, 404(1-2):263-275. https;//doi..org/101007/s11104-016-2839-8

12.Elouear, Z. , Farah Bouhamed, Nesrine Boujelben, Jalel Bouzid .2016. Application of sheep manure and potassium fertilizer to contaminated soil and its effect on zinc, cadmium and lead accumulation by alfalfa plants. Sustainable Environment Research., 26: 131135.https://doi.org/10.1016/j.serj.2016.04.004.

13.Frietas, E. V., and C.W. Nascimento, 2009. The use of NTA for lead phytoextraction from soilo from a battery recycling site. Journal of Hazardous materials, 171(1-3): 833-837.https://doi.org/10.1016/ j.jhazmat.2009.06.069.

14.Ghosh, S., B.R. Wilson, B. Mandal, S.K. Ghoshal and I. Growns. 2010. Changes in soil organic carbon pool in three long-term fertility experiments with different crop-ping systems, inorganic and organic soil amendments in the eastern cereal belt of India. Aust. J. Soil Res., 48(5): 413-420.https://doi.org/10.1071/ SR09089.

15.Jabeen, N., Z.Abbas, M.Iqbal, M.Rizwan, A. Jabbar, M.Farid, S. Ali, M.Ibrahim, and F. Abbas. 2016. Glycinebetaine mediates chromium tolerance in mung bean through lowering of $\mathrm{Cr}$ uptake and improved antioxidant system. Arch. Agron. Soil Sci. 62, 648662.https://doi.org/10-1080/03650340.2015.1082032.

16.Jackson, M.L. 1973. Soil chemical Analysis. Prentice Hall of India (Pvt ). Ltd., New Delhi.

17. Kabata-Pendias, A. and H. Pendias. 2010. Element of Group II. In:"Trace Elements in Soils and Plants". (Kabata-Pendias, A. and Pendias, H., Eds.). CRC Press, Boca Raton, pp 123-164.

18.Kolbas, A., L. Marchand, R. Herzig, E. Nehnevajova and M. Mench. 2014. Phenotypic seedling responses of a metal-tolerant mutant line of sunflower growing on a $\mathrm{Cu}$ - contaminated soil series: potential uses for biomonitoring of $\mathrm{Cu}$ exposure and phytoremediation. Plant Soil, 376(1-2): 377-397.https://doi.org./101007/s11104-013-1974-8.

19.Lucchini, P., R.S. Quilliam, T.H. De Luca, T. Vamerali and D.L. Jones. 2014. Increased bioavailability of metals in two contrasting agricultural soils treated with waste wood- derived biochar and ash. 
Environ Sci Pollut Res., 21(5): 3230-3240.https:// doi.org/10.1007/s11356-013-2272-y.

20.Mando, A., M. Bonzi, M.C.S. Wopereis, F. Lompo and L. Stroosnijder. 2005. Long-term effects of mineral and organic fertilization on soil organic matter fractions and sorghum yield under Sudano- Sahelian conditions. Soil Use and Management, 21(4): 396401.https://doi.org/10.1079/SUM2005339.

21.Manjunatha, G.S., S.N. Upperi, B.T. Pujari, N.A. Yeledahalli and V.B. Kuligod. 2009. Effect of farmyard manure treated with jeevamrutha on yield attributes, yield and economics of sunflower (Helianthus annus L.). Karnataka J. Agric. Sci., 22(1): 198-199.

22.Mishra, A and V.M. Salokhe. 2010. The effect of planting and water regime on rootmorphology, physiology and grain yield of rice. J. Agron Crop Sci., 196, 368-378.

23.Nanjundappa, G., B. Shivaraj, S. Janarajuna and S. Sridharan. 2001. Effect of organic and inorganic sources of nutrients applied alone or in combination on growth and yield of sunflower. Helia., 24(34): 115119.

24.Niu, Z.X., L.N. Sun, T. H. Sun, LI, Y. Shuang and H. Wang. 2007. Evaluation of phyto extracting cadmium and lead by sunflower, ricinus, alfalfa and mustard in hydroponic culture. J. Environ. Sci., 19(8): 961-967. DOI.210.72.129.5

25. Olsen, S.R., C.V. Cole, F.S. Watanable and J.A. Dean. 1954. Estimation of available

26. phosphorus in soils by extraction with sodium bicarbonate. USDA, Circular -939.

27.Radulescu, C., C. Stihi, I.V. Popescu, I.D, Dulama, E, D. Chelarescu and A.Chilian. 2013. Heavy metal accumulation and translocation in different parts of Brassica oleracea L. Rom. Journ. Phys., 58(9-10): 1337-1354.

28.Raymond A. Wauna and Felix E. Okiemen. 2011. Heavy metals in contaminated soils: A review of sources, chemistry, risks and best available strategies for remediation. ISRN Ecology.doi:10.5 $402 / 2011 / 402647$.

29.Rehman, M.Z., M. Rizwan, A. Ghafoor, Asif Naeem., Shafeqat Ali., M. Sabir and M.F. Qayyum. 2015b. Effect of inorganic amendments for in-situ stabilization of cadmium in contaminated soils and its phyto availability to wheat and rice under rice rotation. Environ Sci pollut Res int., 22(21): 16897-906. https:// doi.org/10.1007/s11356-015-4883-y

30.Rehman, M.Z., M. Rizwan, A. Ghafoor, Asif Naeem., Shafeqat Ali., M. Sabir and M.F. Qayyum. 2015b. Effect of inorganic amendments for in-situ stabilization of cadmium in contaminated soils and its phyto availability to wheat and rice under rice rotation. Environ. Sci pollut Res int., 22(21): 16897-906. https:// doi.org/10.1007/s11356-015-4883-y

31.Rizwan, M., S. Ali, M. Adrees, H. Rizvi, M. Zia-urRehman, F. Hannan, M.F. Qayyum, F.Hafeez and Y.S. Ok. 2016b. Cadmium stress in rice: toxic effects, tolerance mechanisms and management: a critical review. Env.Sci. Polln. Res. , 23 (18): 17859-79. DOI:10.1007/s11356-016-6436-4.

32.Robinson, B., Bañuelos, G., Conesa, H., Evangelou, M., Schulin, R., 2009. The Phytomanagement of
Trace Elements in Soil. CRC. Crit. Rev. Plant Sci. 28,240- 266. doi:10.1080/0735268090303542.

33.Sahoo, S.K., D. Sampath kumar and C.R. Reddy. 2009. Production of sunflower (Healianthus annus L.) intercropping system under rabi irrigated conditions. J. Oilseeds Res., 20(2): 284-286.

34.Shaheen, S.M., Rinklebe, J. 2015. Phytoextraction of potentially toxic elements by Indian mustard, rapeseed, and sunflower from a contaminated riparian soil. J. Environ Geochem Health, 37(6): 953-967. https://doi.org/10.1007/s10653-015-9718-8

35.Shittu, O.S., A. Olufemi, A.O.Llori and B.V. Obe. 2015. Monitoring of selected heavy metals uptake by plant around fagbohun dumpsite, Ikere-Ekiti, Ekiti State, Nigeria. Journal of Environmental Science, Toxicology and Food Technology. 9(11): 8591.DOI:10.9790/2402-091118591.

36.Singh, P.K. and S.K. Tewari, 2003. Cadmium toxicity induced changes in plant water relations and oxidative metabolism of Brassica juncea L. plants. J. Env. Biol. 24(1): 107-112.

37.Singh. A. and M. Agarwal. 2013. Reduction in metal toxicity by applying different soil amendments in agricultural fields and its consequent effects on characteristics of radish plants (Raphanusn sativus L.) J. Agr. Sci. Tech., 15 pp: 1553-1564.URI:https:// hdl.handle.net/123456789/4367.

38.Smical, A.I., Vasile Hotea, Vasile Oros, Jozsef Juhasz and Elena Pop. 2008. Studies on transfer and bioaccumulation of heavy metals from soil into Lettuce. Environmental Engineering and Management Journal., 7(5): 609-615.

39.Smith, S.R., 2009. A critical review of the bioavailability and impact of heavy metals in municipal waste composts compared to sewage sludge. Environ. Int. 35(1):142-156.https://doi.org/10.1016/ j.envint.2008.06.009.

40.Standford, S. and L. English. 1949. Use of flame photometer in rapid soil tests of $\mathrm{K}$ and $\mathrm{Ca}$. Agronomy Journal, 41: 446-447.

41.Subbiah, B.V. and G.L.Asija. 1956. A rapid procedure for the estimation of available nitrogen in soils. Curr. Sci., 25: 259-260.

42.Suthar, V., M. Mahamood-ul-Hasan, K.S. Memon and E. Rafique. 2013. Heavy metal phytoextraction potential of spinach and mustard grown in contaminated calcareous soils. Communications in soil science and plant analysis, 44(18): 2757-2770.https:// doi.org/10.1080/00103624.2013.812733.

43.Vassilev, A., Jen-Paul Schwitzguebel, Theo Thewys, Daniel Van der Leile and Jaco Vangronsveld. 2004. The use of plants for remediation of metal contaminated soils. The Scientific World Journal, 4: 934.http:/dx.doi.org/10.1100/tsw.2004.2.

44. Walkley, A. and I.A. Black. 1934. An estimation of the wet acid method for determining soil organic matter and a proposed modification of the chromic and titration method. Soil Science. 37: 29-39.

45.Zhixin Niu, Lina Sun and Tieheng Sun. 2009. Response of Root and Aerial Biomass to Phytoextraction of $\mathrm{Cd}$ and $\mathrm{Pb}$ by Sunflower, Castor bean, Alfalfa and Mustard. Adv. in Environ. Biol., 3(3): 255262.URL.http;//www.insipub.com/.../255-262.pdf. 